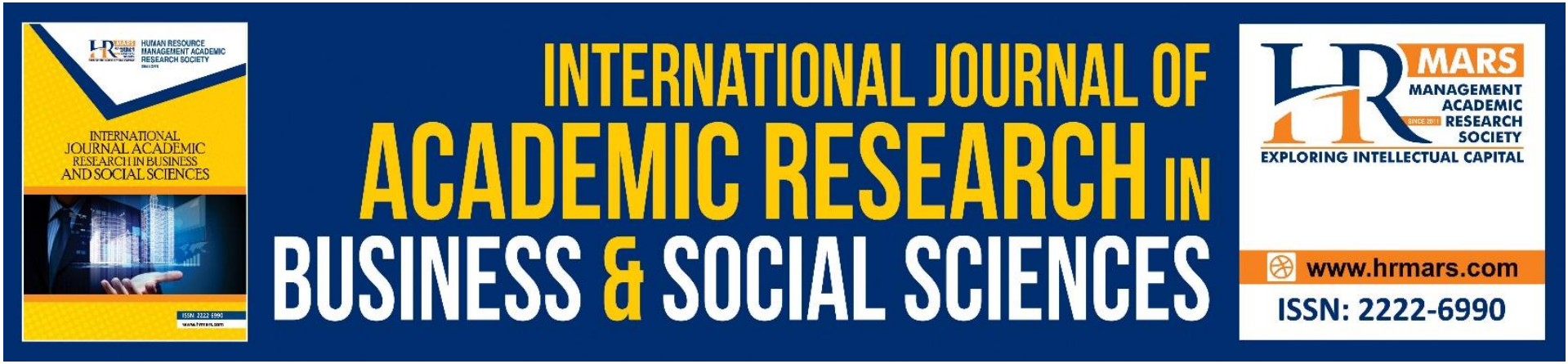

\title{
Untangling the Link between Human Resource Configuration and Performance of Malaysian Manufacturing Organizations: The Mediating Role of Strategic Human Capital
}

Jocelyne Lee, Hasliza Abdul Halim, T. Ramayah

To Link this Article: http://dx.doi.org/10.6007/IJARBSS/v12-i1/11851

DOI:10.6007/IJARBSS/v12-i1/11851

Received: 08 November 2021, Revised: 11 December 2021, Accepted: 29 December 2021

Published Online: 07 January 2022

In-Text Citation: (Lee et al., 2022)

To Cite this Article: Lee, J., Halim, H. A., \& Ramayah, T. (2022). Untangling the Link between Human Resource Configuration and Performance of Malaysian Manufacturing Organizations: The Mediating Role of Strategic Human Capital. International Journal of Academic Research in Business and Social Sciences, 12(1), 462-483.

Copyright: (C) 2022 The Author(s)

Published by Human Resource Management Academic Research Society (www.hrmars.com)

This article is published under the Creative Commons Attribution (CC BY 4.0) license. Anyone may reproduce, distribute, translate and create derivative works of this article (for both commercial and non0-commercial purposes), subject to full attribution to the original publication and authors. The full terms of this license may be seen

at: http://creativecommons.org/licences/by/4.0/legalcode

Vol. 12, No. 1, 2022, Pg. $462-483$

Full Terms \& Conditions of access and use can be found at http://hrmars.com/index.php/pages/detail/publication-ethics 


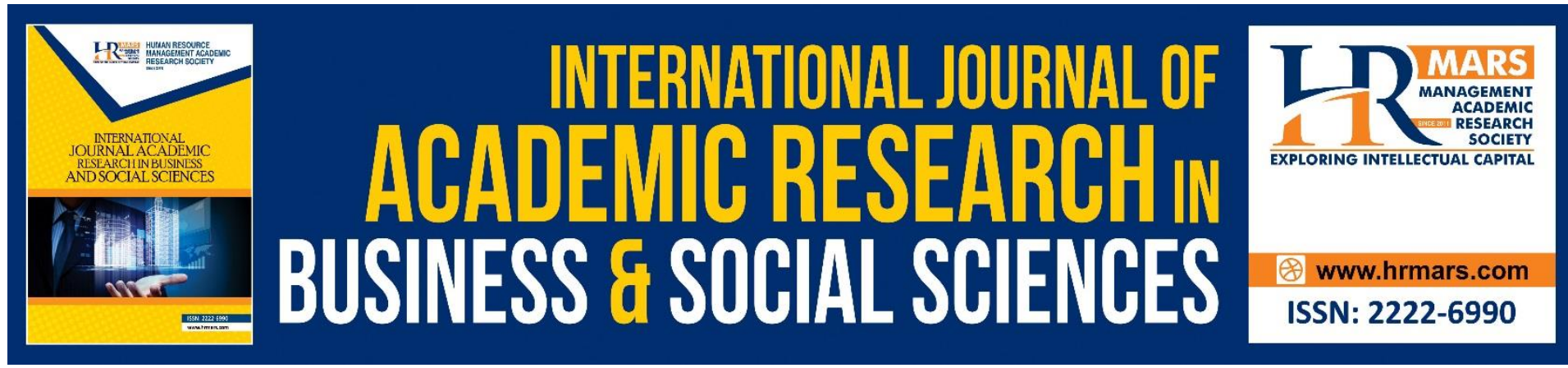

\title{
Untangling the Link between Human Resource Configuration and Performance of Malaysian Manufacturing Organizations: The Mediating Role of Strategic Human Capital
}

\author{
Jocelyne Lee ${ }^{\mathrm{a}}$, Hasliza Abdul Halim ${ }^{\mathrm{b}}$, T. Ramayah ${ }^{\mathrm{c}}$

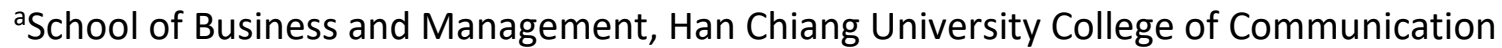 \\ (HCUC) Penang, Malaysia, 'b School of Management, Universiti Sains Malaysia (USM), Penang, \\ Malaysia, 'School of Management, Universiti Sains Malaysia (USM), Penang, Malaysia. \\ Corresponding Author Email: leejl@hju.edu.my
}

\begin{abstract}
Human resource $(H R)$ configuration is very imperative in influencing the performance of an organization. However, the link between HR configuration and organizational performance is yet to be determined and little is known about the variables that could mediate this relation. By analysing data from a single industry, this paper aims to enhance understanding the mediating role of strategic human capital between HR configuration and organizational performance. Strategic human capital is a resource that permits an organization to accomplish competitive advantage and higher performance. To establish strategic human capital, however, is not easily fulfilled. As such it is timely to examine the influence of different types of HR configuration namely commitment, productivity, compliance and collaboration on strategic human capital, the impact on organizational performance and subsequently the mediation effect of strategic human capital. The study uses quantitative research approach where 164 responses were gathered. The data were analysed through PLS-SEM. The results indicated that each dimension of HR configuration affect organizational performance through the influence of strategic human capital. The results showed that the role of strategic human capital is important for the organizations to bring about. More importantly, it provides an insight with empirical evidences that prove the influence of strategic human capital in the relationship between HR configuration and organizational performance.
\end{abstract}

Keywords: Strategic Human Capital, Human Resource Configuration, Manufacturing Performance, Mediator, Perceived Organizational Performance, Perceived Market Performance

\section{Introduction}

The concept of strategic human capital was resulted from the mission of scholars into bringing together and merging comprehensions of human capital studies and strategy studies. Essentially, strategic human capital is "an endeavour to integrate these two domains" (Wright et al., 2014) which eventually help organizations to achieve their strategic competitive goals 
(Gao et al., 2012). An organization's human capital comprises the knowledge, skills and abilities of an individual that brings an advantage to the performance of the organization and with strategic human capital, organization endeavours sustained competitive advantage when its strategic goals are achieved. It also provides economic value towards the organization rather than just towards the individual. The term strategic is achieved when a resource is significant in aiding the expansion of critical capabilities of the organization (Wright et al., 2014). Byrant-Kutcher, Jones and Widener (2009) add that sustainable competitive advantage and enhanced business performance are established when the organization utilizes resources that are difficult for competitors to imitate, which helps the organization increase its efficiency. Having this understanding has motivated this paper to further understand if the sustained competitive advantage of a human capital can be enhanced by human resource configurations.

Several terminologies on human capital are utilized amongst the studies concerning strategic studies and human capital. In reports from the Department of Statistics of Malaysia, different terms for human capital are utilised. The term skilled worker is used in the 11th Malaysia Plan and the New Economic Model for Malaysia as individuals with "Higher Qualifications" that will provide sustainability. The Productivity Report (2016) mentions that human capital is employed for sustained performance. The explanations for human capital in these reports and studies are defined to allow sustainability and it reflects the definition of strategic human capital. In the Malaysian context, human capital is often explained as a form of resource that presents sustained performance. As such, this study submits that terminology associated with human capital that is defined as a tool for sustainability is strategic human capital.

Studies on strategic human capital is rather limited in the Malaysian scene even though human capital research in the Malaysian climate has been sufficient where several scholars have investigated the impact of human capital on economic growth in the Malaysian context (Arphan \& Yap, 2016; Ismail et al., 2014; Samad, 2013). Another limitation on the Malaysian scene is that despite there are several researches and studies on manufacturing, most of it focuses on manufacturing organizations among Small Medium Enterprises (SMEs) (Yusoff et al., 2016). The limited literature has prompted this study.

Commonly, skills, talent, education and innovation represent human capital and it possesses the ability of achieving sustainable growth and development (Shakar \& Aslam, 2015). With possession of the attributes mentioned above, strategic human capital can be viewed as an important player in a country's economic growth (Olimpia, 2013; Su \&Yao, 2016). Leading to the notion of strategic human capital playing a role in growth that has been postulated for some time.

Manufacturing in Malaysia concentrates on the "assembly, testing, design, and development involved in component parts and system production" (Deloitte, 2016). The elements that are focused on by Malaysian manufacturers allow it to reinforce the high- tech sectors. However, the lack of strategic human capital or talent, is holding back the improvement or the growth of the sector (Deloitte, 2016). Selvaratnam (2016) has found that Malaysia is experiencing a shortage of quality human capital. Manufacturing firms have been a source of employment and the Economic Planning Unit (2016) has also reported that the manufacturing sector is the second largest employing sector after the service sector. Malaysian manufacturing sector currently does not possess the knowledge to compete in the production of "high end knowledge-based skill-oriented activities" nor the ability to compete in low cost production (Kam, 2014). The reducing number of strategic human capital that could provide sustainable competitive advantage to the firm has been part of the reason the growth of the sector is 
stationery. Rasiah (2014) has suggested that the performance of the manufacturing sector in Malaysia has descended as there were limited focus on the refining of human capital. With human capital, the firm could utilize its resources quickly and improve management practices that will strengthen the employees' performance (Jin et al., 2010). The need for human capital is vital, however, the need for strategic human capital is slightly overlooked. Human capital does indeed play a role in the establishment and growth of the firm; however, strategic human capital is the one that will provide the firm with its added value of sustained competitive advantage. As Ghazali et al (2015) pointed out, firms that set up in the country not only require skilled employees, they also require expertise that can distinct the firm from others.

Rasiah et al (2015) has found that the low performance of Malaysian manufacturing firm is due to the lack of strategic human capital and that firms that manage to hire quality and strategic human capital have benefited greatly. The absence of strategic human capital in the operation of the organization can lead to the underachievement where the organization does not meet its full production potential. When strategic human capital is not present for the organization's disposal, there are possibilities that there are certain requirements that cannot be met. There are several possible reasons as to the inadequacy of strategic human capital. It can be due to the organization's commitment or preference towards acquiring knowledge (Wang et al., 2008). The human resource configuration of the organization allows employees to either gain knowledge and skills or become strategic human capital or to maintain at their current state and contribute no improvement. The combinations of HR practices, human resource configuration, that enables employees to improve themselves and elevate their abilities from a mediocre employee into a form of human capital that can provide sustainable competitive advantage can be part of the reason why strategic human capital in manufacturing firms are lacking. Having insufficient HR configuration, might lead to poor performance of the strategic human capital that inevitably impacts the performance of the organization (Batistic et al., 2016). attempting to understand further on these factors, this paper aims to investigate:

- The impact of HR configuration namely commitment, productivity, compliance and collaborative on strategic human capital and subsequently the impact on organizational performance.

- Strategic human capital as the mediator between HR configuration and organization performance.

\section{Literature Review and Theoretical Underpinning Strategic Human Capital}

The concept of strategic human capital has becoming the debate among researchers in order to comprehend how organizations can gain improve their organizational performance and sustain competitive advantage through human capital (Olympia, 2013; Brymer, Molloy \& Chadwick, 2015). Becker (1964) has posited that human capital is the knowledge, information, ideas, skills, and health of individuals. Nevertheless, Ployhart and Moliterno (2011) have refined the definition of human capital as the knowledge, skills, abilities and other characteristics of the individual. General human capital has existed in literature for a long time, first existing in economic literature (Gao et al., 2013). On the other hand, strategic human capital is defined as the individuals who possess the knowledge, skills and abilities that provides sustained competitive advantage to the firm (Barney \& Wright, 1998; Amit \& Schoemaker, 1993; Byrant-Kutcher et al., 2009). Whilst human capital is crucial to the 
performance of a firm, strategic human capital has the capacity to sustain and improve the performance of the firm (Xu, Gao, Zhang, Yu \& Song, 2016).

Another perspective to differentiate human capital and strategic human capital is through economic value. The individual human capital might have economic value towards the individual but not to the firm (Gao et al.,2013). Strategic human capital could bring economic value to the organization. Its strategic traits are crucial to understand the variance between human capital and strategic human capital (Zhang, Gao\& Zhang, 2011). Wang, Jaw and Tsai (2012) argue that the trait of being inimitable is a strategic factor imprinted in strategic human capital. In fact, Barney (1991) also posits that, strategic human capital exists when it has the ability or potential to expand the competency and capability of the organization, identify and utilize opportunities and to reduce threat from competitors and the market.

Using the Resource-Based View (RBV), strategic human capital can be illuminated. With the attributes suggested by RBV namely valuable, rare, inimitable and non-substitutable (Barney, 1991), general human capital will be able to morph into strategic human capital. Strategic human capital is seen as an organizations' resource that can provide sustained competitive advantage in which the resources are valuable, rare, inimitable, non-substitutable and not transferable (Byrant-Kutcher, et al., 2009; Liu et al., 2014). Mahdi and Almsafir (2014) also mention that aside from being inimitable, if there is no other organization or competitor that can provide a better option, then the competitive advantage of the firm is already sustained.

\section{Human Resource Configuration}

Lepak and Snell (1999) explains that Human Resource (HR) configurations are a set of HR practices that contribute to employment mode, employment relationships and support the characteristics of human capital. It refers to a group unique procedure or techniques of interchangeable HR practices that are used to manage employees with specific purposes (Batistic et al., 2016; Verburg et al., 2007). It is an assembly HR practices that is carefully designed to manage employees. Among the introduced HR configurations are commitment, productivity, collaboration and compliance-based configurations (Lepak \& Snell, 1999, 2002) and Chow, Huang and Liu, (2008) have posited that these configurations are based on resource-based approach and control-based approach. Lepak and Snell (2002) also add that these HR configurations are an elevation of the generic HR Systems. One can associate HR configurations with HR systems (Kang, Morris, \& Snell, 2007; Verburg, Hartog, \& Koopman, 2007) and replace these terminologies with each other as the common understanding for $H R$ configuration is that it is a composition of several unique HR practices, while HR system similarly also comprises of a collection of HR practices. Seeing as both terminologies carry the same elements, it can be assumed that both HR configurations and HR systems are the same subject. Simply put, HR configuration depicts part of an organizational assets that comprises carefully designed policies which are used to manage employees to achieve their expected goals (Batistic et al. 2016). As mentioned earlier, the categorization of HR configuration include commitment, productivity, compliance and collaborative.

\section{a) Commitment HR Configuration}

In commitment-based HR configuration, the organization focuses on cultivating the full potential of the employee. Chow et al. (2008) argue that this form of configuration explores the employee's involvement in organizational activities and ensures the firm achieves the highest form of return on human capital investments. The said investments are forms of extensive trainings given to the employees in order to cultivate a set of unique skills. 
Employees in this configuration are more equipped with specific skills and have a large amount strategic value. They are very much depended upon by the organization and this shows that these employees are not easily available in the market and nurturing of these needed skills will provide the organization with more returns on productivity (Lepak \& Snell, 1999, 2002; Norris, 2015). This configuration aspires to fulfil an employee's full potential and educates the employees with knowledge that is beneficial to the company (Lepak \& Snell, 1999; Kang et al., 2007; Norris, 2015; Batistic et al., 2016; Lin \& Tang, 2016). Organizations that associate with this configuration are invested in having a long-term relationship with its employees and shows that trust by providing and financing heavily its employees with training, education and equipping them with knowledge that not only benefits the employees but also the organization.

\section{b) Productivity-based HR Configuration}

When an organization decides that it is more worth it to 'buy' its human capital rather than 'make' its own, it is associated with the productivity-based HR configuration. These organizations stress on recruitment and utilization of skills (Lepak \& Snell, 1999) in order to obtain immediate contribution (Chow et al., 2008). Firms are more inclined to short term benefits by obtaining the needed skills that has been developed elsewhere, like individuals who are trained in professions (Norris, 2015) instead of being firm specific. In other words, organizations are more willing to offer higher wages to obtain the human capital that they need rather than investing in training and development (Chow et al., 2008).

\section{c) Compliance HR Configuration}

Compliance is a form of HR system that works using rules and regulations. This configuration requires no particular specific skills from its employees, hence the need to manage them using terms and conditions. Chow et al (2008) have argued that that organizations rely on the enforcement of rules and regulations in order to achieve a pre-established goal and employees in this kind of working environment are often very used to being monitored and managers having power over them. Employees with minimal strategic value and uniqueness and often obtained externally through work contacts are grouped into this configuration (Lepak and Snell, 2002). Employees related to this configuration are related to their organizations purely by their economic exchange of compensation for work and there are minimal procedural standards in this component (Norris, 2015). Batistic et al (2016) have concluded that compliance HR configuration is impeccably when it features minimal practices and rules for managing employees, however, it is highly transactional and short term oriented.

\section{d) Collaborative HR Configuration}

The collaborative configuration is a HR system which encourages and rewards cooperation, collaboration and information sharing in the organization. Employees who are categorized in collaborative HR configuration frequently possess high unique skills but with low strategic value (Lepak \& Snell, 1999). This configuration concentrates on group based and democratic practices, whereby by aggressive behaviour and competition is avoided (Chow et al., 2008). A simple explanation is that collaborative HR configuration is a meek and accommodating one where participants in this system are usually encouraged to work together in peace rather than to fight for credit or attention. In this respect, organizations focus on process facilitation and invest in teambuilding activities and endorses structural partnerships (Chow et al., 2008; 
Cabrales et al., 2009; Norris, 2015). This system helps the organizations to improve trust and encourage information and knowledge sharing.

\section{Perceived Organizational Performance and Perceived Market Performance}

Organizational performance is a variable that has been widely investigated by almost every school of thought. It is considered the ultimate dependent variable for researchers in the wide field of management (Richard et al., 2009). Performance is a common fixture in management research that its definition refers to rarely explicitly justified, instead, its appropriateness is just assumed (Liao \& Wu, 2009; March \& Sutton, 1997). Despite organizational performance being explored so often, in almost all relatable school of thoughts, there is no standard or fixed definition or measurement available for this construct (Richard et al., 2009; Kirby, 2005; Croteau \& Bergeron, 2001). Seeing that there is not a fixed method in measuring organizational performance and most of its elements being assumptions, there are many aspects that can be used to measure it. The more common approach used to measure performance would be the firms' financial performance (Richard et al., 2009).

Different scholars have introduced different measurements, like Croteau and Bergonan (2001) have measured performance with sales growth and profitability; Calantone, Cavusgil and Zhao (2002) measured the firms' performance with four items, Return on Investments, Return on Assets, Return on Sales and overall profitability. Another example of measurement is the five items presented by Agarwal, Erramilli and Dev (2003), which is service quality, customer satisfaction, employee satisfaction, gross profit margin, and market share. There are several methods and items used in measuring performance, and Delaney and Huselid (1996) measured organizational performance with perceived organizational performance and perceived market performance.

Perceived organizational performance would be on how the organization has been doing, in terms of the its' ability to attract and retain its employees, the satisfaction of the customers, the quality of the products or services of the firm and the development of the new products or services. This element can be seen as a measure of the firms' evolution, advancement and progress. Perceived market performance, on the other hand, leans towards a monetary aspect or a financial measure of the firm's performance. The organizations' competence in marketing aspects, sales, profitability and market share are included in the items that are measured.

\section{Hypotheses Development}

\section{Human Resource Configuration and Strategic Human Capital}

The configuration approach towards human resource practices is explained as a form of patterns with several variables and how these variables will affect the organizational outcomes. The HR configuration introduced by Lepak and Snell $(1999,2002)$ links human capital and the configurations through arguments of employment approaches. The value and uniqueness of human capital will influence the structure of the practices of human capital. Employment modes can be understood as the commitment of the organizations towards the employee. How the organization opts to work with the employees will decide what HR practices to be utilized in the relationship. The types of practices implemented will affect the employees' behavior and performance (Mossholder et al., 2011; Batistic et al., 2016). When an organization decides to raise involvement from the employee to the firm's operation and to maximize on investment on human capital, it adopts the commitment-based configuration 
(Chow et al., 2008). Productivity configuration is the organizations attempting to increase on short-term productivity and improving the existing job environment (Monks et al., 2013). An organization's activities are usually regulated and strict, then compliance configuration is applied to ensure jobs are well defined and easily master (Monk et al., 2013). The final configuration is collaboration. In this practice, teamwork, cooperation and sharing are highly encouraged whereby team building is often carried out (Chow et al., 2008).

Each quadrant carries a different purpose individually, built on the strategic value and uniqueness of human capital. Job scope, recruitment methods, training, performance appraisal and rewards are part of the criterion the quadrants are all built upon. These factors are critical towards HR systems or configurations that are in question in this study. There is always the possibility that the bundle of approaches in HR known as configurations allows the employees' potential to be maximized and could achieve the theory criterion in RBV and produce strategic human capital. Based on the explanation above, the hypotheses below are established:

H1: Commitment has a positive relationship with strategic human capital

$\mathrm{H} 2$ : Productivity has a positive relationship with strategic human capital

H3: Compliance has a positive relationship with strategic human capital

$\mathrm{H} 4$ : Collaboration has a positive relationship with strategic human capital

\section{Strategic Human Capital and Performance}

An organization's strategic human capital plays an important role in contributing towards its performance and competitive advantage. Previous studies have found that strategic human capital influences the performance of the organization (Crook et al., 2011, Mahsud et al., 2011; Felicio et al., 2014; Samagaio \& Rodrigues, 2016). Strategic human capital plays a vital role due to its characteristics, which is the knowledge, skills, abilities and other points of an individual. These characteristics allow the organization to employ value creation activities and synchronize the organization's strategies and practices accordingly that will ultimately affect firm performance (Hsu, 2008). In fact, it is valuable and rare to an organization as it is a difficult task to obtain and find any form of resources that will promise high performance in an organization (Lado \& Wilson, 1994). In fact, strategic human capital is valuable to the organization due to its individuality of knowledge, skills and capabilities that cannot be easily replicated (Wright et al., 1994). When strategic human capital is mentioned, what comes to mind is the exploitation of available human capital to achieve a certain level of advantage that allows to firm to have distinct characteristics and prolonged superior performance. Importantly, strategic human capital should be an asset that is of great benefit to the organization. Firm specificity is a trait of strategic human capital that facilitates opportunistic behaviour (Widener, 2004). It is the extent to which an employee' skill and knowledge is difficult to shift, convey or relocate. Behavioural uncertainty is another characteristic of strategic human capital, and maybe rationalized as causal ambiguity, whereby there is not much specificity of an employees' routine that it can be repetitive and supervised (ByrantKutcher et al., 2009). Causal ambiguity then leads to the third characteristic, the spread of strategic human capital. This aspect is the activities that are repetitive, as described as causal ambiguity, and yet it is still inimitable due to it being embedded in a mass of resources (Widener, 2004; Byrant-Kutcher et al., 2009).

Despite many researchers having mentioned the relationship of human capital and organizational performance, a strategic view of sustained competitive advantage is scarcely investigated. Approaching the relationship with human capital providing prolonged value has 
been mildly investigated and is what the present study is attempting to do. Byrant- Kutcher et al (2009) states that strategic human capital is part of reason that enables a firm to achieve sustainable competitive advantage. Literature from economic and strategy perspective has postulated that firms that are able to grasp and handle strategic resources are often able to create competitive advantage, earn economic rents and have a foundation to build sustained competitive advantage on. In fact, strategic human capital may provide impact to perceived organizational performance and perceived market performance. Excellent strategic human capital is expected to influence organization performance in terms of its' ability to attract and retain its employees, the satisfaction of the customers, the quality of the products or services of the firm and the development of the new products or services. In contrast, strategic human capital is predicted to have impact on market performance from the perspective of monetary aspect or a financial measure of the firm's performance. The organizations' competence in marketing aspects, sales, profitability and market share are included in the items that are measured. Based on this explanation, the hypotheses are proposed as below:

H5: Strategic Human Capital has a positive effect on Organizational Performance H6: Strategic Human Capital has a positive effect on Market Performance

\section{Mediation Effect of Strategic Human Capital on HR Configuration and Performance}

In human capital theory, benefits are obtained from investments on people (Sweetland, 1996). The most common form of investments is education. Investing in tutelage is something that has been considered most important to human capital (Becker, 2008). HR configuration is one of the key characteristics of human capital. From a competitive point of view, RBV, HR configuration is the most unique and inimitable form of resource. It is an assembly $H R$ practices that is prudently planned to manage employees in order to business performance. Different types of HR configuration namely commitment, productivity, collaboration and compliance-based configurations (Lepak \& Snell, 1999, 2002) are predicted to have influence on organizational and market performance of an organization. As such, it is predicted that the inclusion of strategic human capital as the mediator will explain further the relationship between HR configuration and business performance. Lepak and Snell (2002) have posited that HR configurations are an advancement of the generic HR systems which will eventually improve organizational performance by leveraging on resources which are rare, valuable, inimitable, non-substitutable as well as and not transferable. This indicate that strategic human capital is crucial in this relationship and serves a source of sustainable competitive advantage in an organization. HR configurations is a common understanding for HR system that refer to a composition of several unique HR practices that are pertinent in establishing strategic human capital. This is very important for organization to elevate its strategic human capital in order to accomplish its expected goals (Batistic et al., 2016). Based on the above explanation, the strategic human capital is hypothesised as a mediator for each of HR configurations (commitment, productivity, compliance and collaboration) and perceived organizational performance and perceived market performance.

H9: $\quad$ Strategic human capital positively mediates the relationship between commitment and perceived organisational performance

H10: Strategic human capital positively mediates the relationship between productivity and perceived organisational performance 
H11: Strategic human capital positively mediates the relationship between compliance and perceived organisational performance

H12: Strategic human capital positively mediates the relationship between collaboration and perceived organisational performance

H13: Strategic human capital positively mediates the relationship between commitment and perceived market performance

H14: Strategic human capital positively mediates the relationship between productivity and perceived market performance

H15: Strategic human capital positively mediates the relationship between compliance and perceived market performance

H16: Strategic human capital positively mediates the relationship between collaboration and perceived market performance

\section{Research Methodology}

This study is classified as a cross sectional design study, in which the data needed is collected only once instead of collecting it throughout a period of time (Zikmund et al., 2013). The sample for this study includes manufacturing organizations in Malaysia and this information was obtained from the Federation of Malaysian Manufacturers (FMM) year 2018. The FMM reported that there are 3846 manufacturers registered with the body. Firms with more than 200 employees were chosen as sample for the study as SME Corp and FMM define SMEs as firms with employees not exceeding 150 employees and firms with more than the mentioned amount is considered as large firms. There are currently 1015 registered large manufacturers in the FMM directory. The inclusion criteria for this study are large manufacturing firms is due to large firms having more employees compared to SMEs, making the need for strategic human capital greater. Secondly, large firms are included due to its ability to recruit qualified human capital and has better use of human capital compared to SMEs (Economic Planning Unit, 2014). The unit of analysis is the managers or executives in charge of human resources who have direct contact with employees and has knowledge of the workforce performance. The sampling technique employed was the simple random sampling method; whereby all the components in the population is allowed equal opportunity to be included in the sample (Zikmund et al., 2013). Simple random sampling is preferred as there is no comparison between the sample groups and also the study is not investigating on differences of the variables. When determining the sample size, it is implied by Hair, Hult, Ringle and Sarstedt (2014) that the sample size should be equal to the larger of 10 times the largest number of structural paths directed at a construct in the structural model. The general rule of thumb is to have at least five times as many observations as the number of variables that is to be analysed and the more acceptable sample size would be of the 10:1 ratio. However, the G*Power was employed to calculate the minimum sample size. The G*Power analysis tool is often used in studies as the statistical technique used to calculate the minimum sample size (Faul et al., 2009). The results of $G *$ Power indicated that the minimum sample size calculated is 134 .

A set of structured questionnaires was crafted from previous researchers and 7-point Likert Scale was used to rate their preference on a scale provided ranging from a positive attitude to a negative one. An interpretation of the scales used is also provided in the questionnaires provided for the respondents to clearly understand and the questionnaire will be in English. Established measures from related subjects are amalgamated in the questionnaire to assess the framework of this study through literature reviews. Strategic Human Capital variable was 
to measure respondents' agreeability towards strategic human capital, the measurement was developed by Widener (2004) with 17 questions. For HR configuration, the measurement was adopted from Lepak and Snell (2002) consisting of four (4) constructs and 51 questions. Finally, Delaney and Huselid (1996) measured organizational performance in two perceptual measures, perceived organizational performance and perceived market performance. The items measured is adopted in this study and contains 11 items in total. Survey questionnaires were distributed through electronic mail, post and direct to the respondents i.e. HR managers in large manufacturing organizations across Malaysia. For rationalization purpose and to inflate the number of potential respondents, 500 manufacturing organizations from the total of 1015 manufactures were selected randomly from the FMM Directory. Upon completing this procedure, a total of 172 responses were received. However, only 164 responses were usable with eight (8) responses discarded as there were too many missing values or no variation in the responses at all.

\section{Data Analysis}

We used partial least squares analysis as suggested by Hair, Howard and Nitzl (2020) with the use of SmartPLS 3.2.9 (Ringle et al., 2015). SmartPLS is a second generation structural equation modelling technique that employs confirmatory composite analysis (CCA; Hair et al., 2020) to assess the measurement model (validity and reliability of the measurement items) and then in the second stage assess the structural model (relationships between constructs).

Since data was collected using a single source, we first assessed whether common method bias is a serious problem in our research by following the recommendations of Kock (2015) by assessing the full collinearity. This method creates a dummy random variable and the regresses all the variable in the model against this random dummy variable. The guideline is that if the VIFs from this analysis is $>5$ then we have a problem of common method bias. Our analysis yielded VIF values which were all lower than 5 as such common method bias is not a serious problem in our research.

\section{Measurement Model}

To assess the measurement items, we used the loadings, average variance extracted ad composite reliability. Ramayah et al (2018) suggest that loadings should be $\geq 0.7$, AVE $\geq 0.5$ and $C R \geq 0.7$ for a valid a reliable measure. Since we had a large number of items the loadings are not shown but eh AVEs and CRs are shown in Table 1. The AVEs were all higher than 0.5 and the CRs higher than 0.7. The skewness and kurtosis of the variables were also within the \pm 1 indicating the variables are univariate normally distributed.

The second validity that we used was discriminant validity. Franke and Sarstedt (2019) suggested to use the HTMT criterion (Henseler et al., 2015) to assess discriminant validity. The suggested 2 cut off points which were $\mathrm{HTMT}_{0.85}$ and HTMT $\mathrm{H}_{0.90}$. If the HTMT ratios are lower than the cut-off values, then we can conclude that the measures are distinct. As shown in Table 2, all the values were less than $\mathrm{HTMT}_{0.90}$. Thus, we can conclude that the measures of our study have both convergent and discriminant validity. 
INTERNATIONAL JOURNAL OF ACADEMIC RESEARCH IN BUSINESS AND SOCIAL SCIENCES

Vol. 12, No. 1, 2022, E-ISSN: 2222-6990 @ 2022 HRMARS

Table 1

Mean, Standard Deviation, Skewness, Kurtosis and Measurement Quality

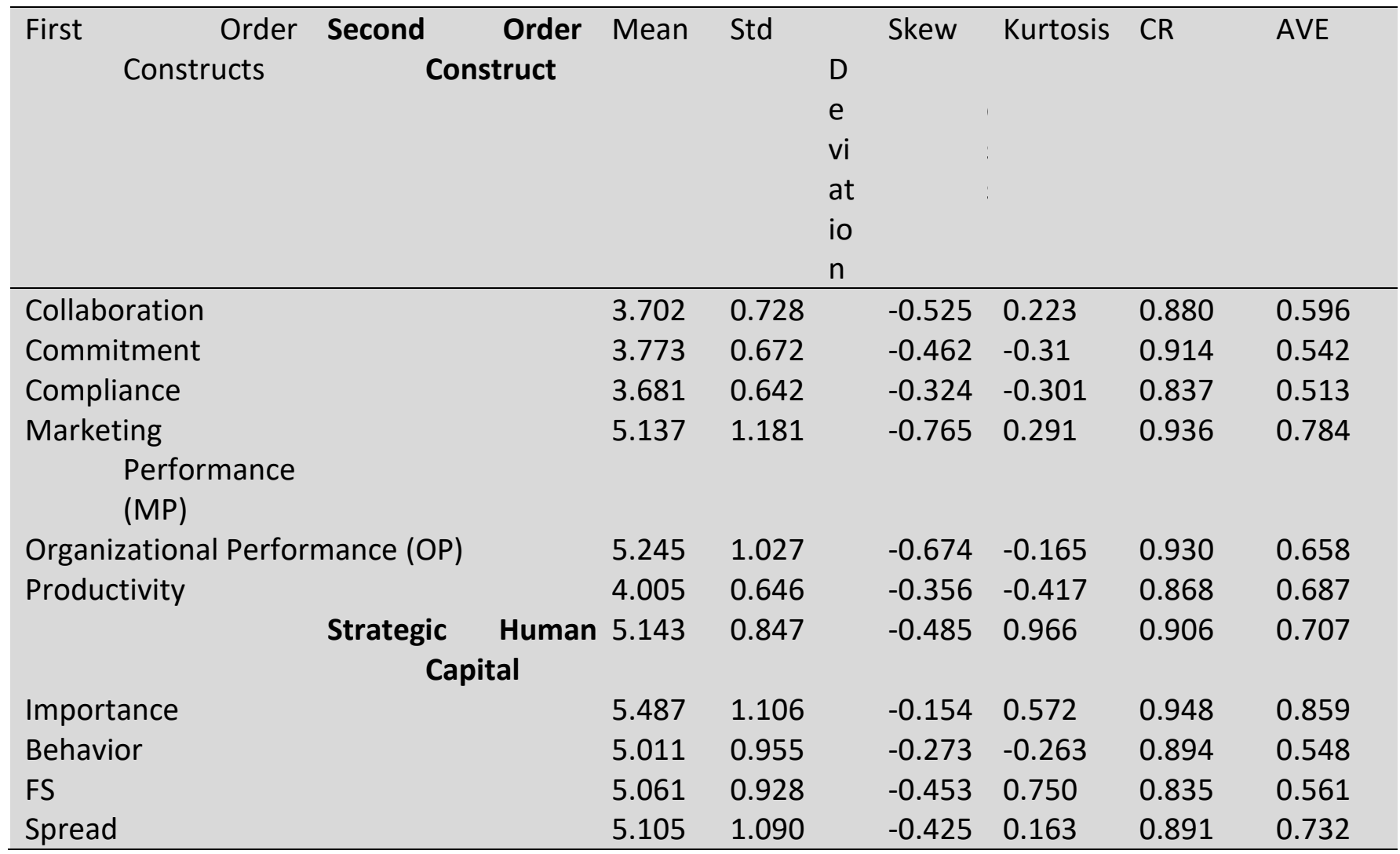

Table 2

Discriminant Validity (HTMT Ratio)

\begin{tabular}{llllllll}
\hline Constructs & 1 & 2 & 3 & 4 & 5 & 6 & 7 \\
\hline Collaboration & & & & & & & \\
Commitment & 0.842 & & & & & & \\
Compliance & 0.747 & 0.831 & & & & & \\
Marketing Performance & 0.601 & 0.731 & 0.681 & & & & \\
Organizational Performance & 0.613 & 0.821 & 0.682 & 0.801 & & & \\
Productivity & 0.737 & 0.877 & 0.652 & 0.582 & 0.722 & & \\
SHC & 0.690 & 0.786 & 0.775 & 0.781 & 0.805 & 0.701 & \\
\hline
\end{tabular}

\section{Structural Model}

We first tested the data for multivariate normality using the website Webpower statistical power analysis online (https://webpower.psychstat.org/models/kurtosis/). The analysis showed that the Mardia's multivariate skewness was $8.182(t=223.639, p<0.01)$ and kurtosis was 78.495 ( $t=8.839, p<0.01)$ indicating a non-multivariate normal data. Thus, we ran a bootstrapping with 5,000 resamples (Hair et al., 2020) to generate the beta values, standard errors, $t$-values, $p$-values and confidence intervals.

We first tested the direct relationships between the independent variables and the mediator. Commitment $(b=0.327, p<0.01)$, Productivity $(b=0.125, p<0.05)$, Compliance $(b=0.265$, 
$p<0.01)$ and Collaboration $(6=0.123, p<0.05)$ were positively related to Strategic Human Capital (SHC). The $R^{2}=0.542\left(Q^{2}=0.370\right)$ indicating that all the 4 independent variables can jointly explain $54.2 \%$ of the variance in SHC. SHC $(B=0.725, p<0.01)$ was positively related to Organizational Performance explaining $52.5 \%$ of the variance and $\mathrm{SHC}(b=0.697, p<0.01)$ was also positively related to Marketing Performance explaining $48.5 \%$ of the variance.

To test the mediation hypotheses developed, we followed the method of bootstrapping the indirect effects developed by Preacher and Hayes $(2004 ; 2008)$. According to Preacher and Hayes (2004; 2008), if the bootstrapped confidence intervals do not straddle a 0 then the mediating effect is statistically significant. As can be seen from Table 4, all the mediating beta values were significant with their respective bootstrapped confidence intervals did not straddle a 0 thus all the 8 mediation hypotheses, $\mathrm{H} 7, \mathrm{H} 8, \mathrm{H} 9, \mathrm{H} 10, \mathrm{H} 11, \mathrm{H} 12, \mathrm{H} 13$ and $\mathrm{H} 14$ were all supported.

Table 3

Hypothesis Testing Direct Relationship

\begin{tabular}{|c|c|c|c|c|c|c|c|c|}
\hline Hypothe & Relationship & Std & Std & t-value & p-value & $\mathrm{BCl} \mathrm{LL}$ & $\mathrm{BCl}$ UL & $f^{2}$ \\
\hline $\mathrm{s}$ & & & B & $E$ & & & & \\
\hline $\mathrm{i}$ & & & e & $r$ & & & & \\
\hline $\mathrm{s}$ & & & $t$ & $r$ & & & & \\
\hline & & & $a$ & 0 & & & & \\
\hline & & & & $r$ & & & & \\
\hline $\mathrm{H} 1$ & $\underset{\text { SHC }}{\text { Commitment }} \rightarrow$ & 0.327 & 0.092 & 3.564 & $p<.001$ & 0.176 & 0.471 & 0.064 \\
\hline $\mathrm{H} 2$ & Productivity $\rightarrow$ SHC & 0.125 & 0.069 & 1.814 & 0.035 & 0.018 & 0.242 & 0.022 \\
\hline H3 & Compliance $\rightarrow$ SHC & 0.265 & 0.068 & 3.897 & $p<.001$ & 0.148 & 0.371 & 0.074 \\
\hline $\mathrm{H} 4$ & $\begin{array}{c}\text { Collaboration } \\
\text { SHC }\end{array}$ & 0.123 & 0.071 & 1.725 & 0.042 & 0.011 & 0.237 & 0.020 \\
\hline H5 & $\mathrm{SHC} \rightarrow \mathrm{OP}$ & 0.725 & 0.039 & 18.465 & $p<.001$ & 0.647 & 0.778 & 1.106 \\
\hline H6 & $\mathrm{SHC} \rightarrow \mathrm{MP}$ & 0.697 & 0.045 & 15.393 & $p<.001$ & 0.607 & 0.758 & 0.943 \\
\hline
\end{tabular}


INTERNATIONAL JOURNAL OF ACADEMIC RESEARCH IN BUSINESS AND SOCIAL SCIENCES

Vol. 12, No. 1, 2022, E-ISSN: 2222-6990 @ 2022 HRMARS

Table 4

Hypothesis Testing Indirect Relationships

\begin{tabular}{|c|c|c|c|c|c|c|c|}
\hline Hypoth & Relationship & Std Beta & Std & t-value & $p$-value & $\mathrm{BCl} \mathrm{LL}$ & $\mathrm{BCl} U \mathrm{~L}$ \\
\hline & \multicolumn{7}{|l|}{ 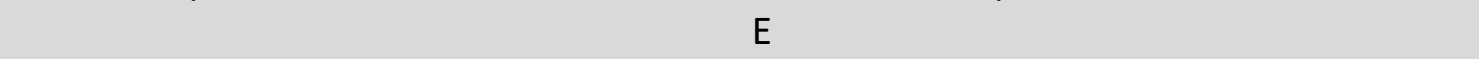 } \\
\hline & \multicolumn{7}{|c|}{$r$} \\
\hline$i$ & \multicolumn{7}{|c|}{$r$} \\
\hline & \multirow{2}{*}{\multicolumn{7}{|c|}{ o }} \\
\hline & & & & & & & \\
\hline $\mathrm{H} 7$ & $\begin{array}{c}\text { Commitment } \rightarrow \mathrm{SHC} \rightarrow \\
\text { OP }\end{array}$ & 0.237 & 0.071 & 3.324 & $p<.001$ & 0.123 & 0.354 \\
\hline $\mathrm{H} 8$ & $\begin{array}{c}\text { Productivity } \rightarrow \text { SHC } \rightarrow \\
\text { OP }\end{array}$ & 0.090 & 0.050 & 1.798 & 0.036 & 0.012 & 0.177 \\
\hline H9 & $\begin{array}{c}\text { Compliance } \\
\text { OP }\end{array}$ & 0.192 & 0.051 & 3.780 & $p<.001$ & 0.106 & 0.273 \\
\hline H10 & $\begin{array}{c}\text { Collaboration } \rightarrow \mathrm{SHC} \rightarrow \\
\text { OP }\end{array}$ & 0.089 & 0.051 & 1.734 & 0.041 & 0.001 & 0.170 \\
\hline H11 & $\begin{array}{c}\text { Commitment } \\
\mathrm{MP}\end{array}$ & 0.228 & 0.070 & 3.255 & 0.001 & 0.116 & 0.342 \\
\hline $\mathrm{H} 12$ & $\begin{array}{c}\text { Productivity } \\
\text { MP }\end{array}$ & 0.087 & 0.048 & 1.798 & 0.036 & 0.011 & 0.168 \\
\hline H13 & $\begin{array}{c}\text { Compliance } \\
\text { MP }\end{array}$ & 0.185 & 0.049 & 3.754 & $p<.001$ & 0.102 & 0.264 \\
\hline $\mathrm{H} 14$ & $\begin{array}{c}\text { Collaboration } \rightarrow \mathrm{SHC} \rightarrow \\
\mathrm{MP}\end{array}$ & 0.086 & 0.050 & 1.726 & 0.042 & 0.001 & 0.164 \\
\hline
\end{tabular}

\section{Discussion and Conclusion}

This paper suggests that HR configuration has the potential to act as an antecedent towards strategic human capital, allowing general human capital to achieve strategic value by providing it the needed component to achieve sustained competitive advantage and improved organizational performance. Human resource configuration is a combination of practices and policies that is applied to aid employees in achieving their goals (Batistic et al., 2016; Lepak \& Snell, 2002) and elevates the 'strategic' value of human capital (Lepak \& Snell, 2002). When adopted accordingly into the organization, it will aid the creation of strategic value towards the human capital of the organization. The direct relationships suggest that all variables under HR configuration have a positive relationship with strategic human capital. Hypothesis 1 proposes that commitment has a positive relationship with strategic human capital, and the results indicated that manufacturing firms in Malaysia put the investments towards the internal development and focused more on uplifting the employee's skills in the organizations. In fact, this shows that the employers are providing more training and development to their employees. Similarly Hypothesis 2 is also supported with positive significant relationship with strategic human capital. Practices and policies in productivitybased HR are regarding the organization's choice on 'buying' its human capital, instead of 'making' their own, and they are more willing to pay for the skills rather than invest in developing it (Chow et al., 2008). Lepak and Snell (2002) have suggested that human capital possess a certain value towards the productivity configuration. The result obtained from this study builds on the findings of Lepak and Snell (2002), by checking on strategic human capital 
in place of human capital. It can be interpreted that manufacturing organizations in Malaysia, in order to obtain strategic human capital, would rather buy than train.

As for Hypothesis 3, compliance HR configuration is important to enhance strategic human capital in which the organizations believe that the employees need to constantly be supervised. There is a constant need of rules and regulations in this configuration. Based on the results of the study, it can be gathered that Malaysian manufacturing organizations trust that the application of rules and regulations will lead to strategic human capital. This result provides an unforeseen finding as there is past literature that proposed a weaker application of the compliance configuration would lead to more effective human capital and performance (Batistic et al., 2016, Hansen et al., 2017). Batistic et al. (2016) did suggests that although it is helpful to allow loose regulations, this practice depends heavily on the characteristics of the employee themselves, hence, the application of the compliance configuration would be beneficial as well. Chow et al (2008) also adds that in high-power-distance cultures, the compliance configuration is well accepted. Finally, for $\mathrm{H} 4$ on collaboration HR configuration, this result suggest that collaboration is pertinent in having a positive strategic human capital. Lepak and Snell (2002) have posited that the practices in this element is non-traditional and this configuration is found to have strong support in the contribution of human capital. And, the practice of externalizing resources is a preferred option for a majority of large organizations in Malaysia (Sim et al., 2016; Sim \& Yee, 2016; Douglas, 2016). It can be surmised that Malaysian manufacturing organizations have agreed that collaboration configuration lead to enhanced strategic human capital.

This study also explores the influence of strategic human capital on organizational performance amongst Malaysian large manufacturing firms. Strategic human capital is a resource that helps firm obtain sustained competitive advantage. In context of this study, strategic human capital was tested against both perceived organizational and market performance. Hypothesis 5 and hypothesis 6 were accepted with high T-values. The positive relationship between strategic human capital and organizational performance is consistent with Hsu (2008); Felicio et al (2014), whereby both studies found that strategic human capital effects not only the non-financial performance of the organization but also the market performance. The results of organizational performance indicated that the firm's ability to secure revenues (Anderson \& Fornell, 2000), subsequently indicating that strategic human capital could possibly be the reason why an organization pertain its future revenues. Crook et al (2011) states that when the organization increases its strategic human capital, its performance also improved. Walker and Brown (2004); Reijonen (2008) have admitted that measuring both types of performance provide a more in-depth description on the overall organization's performance.

The findings are also very interesting as all the mediation (indirect relationship) hypotheses were accepted. With this knowledge, HR configuration relates positively to organization performance by leveraging on strategic human capital. Large manufacturers in Malaysia should pay attention into the generating of strategic human capital in the interest of the organization's performance. This indicates that the manufacturers in Malaysia understand that their strategic human capital is substantial in producing and obtaining quality products and durability to endure ruthless market conditions.

\section{Theoretical Contribution}

There are several contributions in terms of theory that can be drawn from this study that could benefit those in the academic and research field. First and foremost, theoretical wise, 
the role of resource-based view is focused upon and is integrated with dynamic capabilities and human capital theory that relates the organization practices of investing in resources to for sustainable competitive advantage. These theories state that organisations require resources and capabilities that are valuable, unique, non-substitutable and hard to imitate in order to generate sustainable competitive advantage. To have that traits, human resource configuration as an antecedent towards strategic human capital, adopting resource-based view as the main theory that is the foundation of the relationship, alongside human capital theory that is based on investments towards strategic human capital. Additionally, dynamic capabilities is also integrated in the framework, in terms of allowing the factors for the development of strategic human capital. Through these theories, this study learns how HR managers could commission resources to develop sustained competitive advantage. Strategic human capital can be enhanced by resources specifically human resource configuration. In a sense, this study adds to the current stock of knowledge by integrating the theories to provide a more comprehensive view on how manufacturing organizations can improve their workforce into achieving sustained competitive advantage (strategic human capital) and accomplishing organizational performance targets.

Another contribution made is on HR configurations utilised to support growth of a human capital to strategic human capital. The notion is that HR configurations enlighten the HR manager on what forms of HR practices and procedures that will support the growth of mere human capital to one with strategic values and sustained competitive advantage. This study eventually assesses strategic human capital as a mediator between configuration and organizational performance of manufacturing organizations in Malaysia. Fundamentally, the overall model is potentially useful in providing information on the study on strategic human capital from the perspective of large organizations.

\section{Practical Implications}

Results from the study shows that HR configuration tested have positive relationships with strategic human capital. HR managers could focus on the promotion of organizational goals and objectives, as well as knowledge and information distribution. For HR configuration, managers should understand the practices that aids in the obtaining and retaining as well as training the workforce that will ultimately lead to strategic human capital. When strategic human capital exists in the organization, it will be able to withstand certain obstacles and prolong its prosperity. In terms of practical contributions, the results of this study show that of the four configurations, Malaysian manufacturing organizations identify all the configurations as important elements to improve strategic human capital. Seeing as to the preferred method of achieving organizational goals is to procure rather than create skilled workforce, HR managers should always be prepared for a possible high turnover rate in terms of employment. Also, this is finding is beneficial for higher institutes and training centres in the country as they can prepare their students according to market demands. Since most manufacturing organizations prefer already trained and skilled workers, education institutes can model its courses and programs to cater for this demand. Additionally, HR managers should also place more emphasis on enforcing rules and regulations, as well as preparing them in a logical manner according to the situation. Managers should understand the gravity of the situation and enforce the rules accordingly instead of just blindly following already set regulations that might be outdated.

These observations could shed some light for HR managers and policy makers on the formulation of methods in developing a workforce that helps achieve sustained competitive 
advantage and organizational performance. Also, organizations are advised to search for the forms of practices and policies to deal with the growth of their workforce. Managers should consider if enough attention is paid to encourage interactions among employees and their networks. Relationships that are build require nurturing and encouragement to ensure that information is not withheld. Having found that strategic human capital influences both aspects of organizational performance, it is suggested that organizations pay attention to understand more thoroughly what method is most suitable for their organization in terms of obtaining strategic human capital.

Practically, the finding suggests that the organization is paying attention on the organizational performance of the organization but at the same time the managing body should also lean towards the market performance aspect of the organization. The organization should try to provide programs that would probably improve both organizational performance of the organization. The results of this study could provide understandings for decision makers to sustain their competitive advantage in the harsh market.

\section{Limitations and Future Research}

Whilst the results from this study offers constructive insights into the fine points of the various constructs used in this study, there is still the presence of limitations that need to be accounted for when conducting an effective study. First, since this study is restricted a specific country, industry and organizational size (large manufacturers), there is a possibility that the external validity and generalizability of the study is restrained. This restrain is amplified by the fact that even though some large manufacturers were listed in the FMM directory as having active operating businesses, they were found to be with inactive operation or uncooperative. Perhaps, future research work on strategic human capital should be encouraged to cross-validate the results of the present study, and to determine the generalizability of these results by collecting data from all levels of the organization to substantiate and validate the results. Besides that, it would be interesting to test model's applicability through on to other large organizations aside from manufacturing organizations, probably the service industry or SMEs.

Second limitation refers to its dependence on a single respondent (HR managers of large manufacturers). It would be interesting and thought provoking to have respondents from all levels of the organization, however, due to cost constraint, this study is limited to only the HR managers of large manufacturers. Regarding self-report single respondents, Podsakoff and Organ (1986) have insinuated that data obtained might be subjected to social desirability bias. Nonetheless, despite the disadvantage of single respondents, it is preferred by most researches. Also, the guarantee of anonymity may reduce the bias, plus, the utilization of common method bias using the marker variable has shown that there is no such bias.

Thirdly, this study is also constrained by the cross-sectional design implemented. The study reflected on the current state of large manufacturers in Malaysia that foes not allow this study to delve into the long term and short effects of the proposed constructs towards strategic human capital. Also, even though almost all plausible directions for the framework's pathway had been performed, the longitudinal research is wanted for the purpose of observing the relationship's causality direction and identify possible process of reciprocal. It would be beneficial for to apply a longitudinal study whereby the changes and flow of knowledge can be examined as time progresses to fully understand the linkage between the constructs in this study. Another interesting option for exploration is to incorporate the mixed-methods approach to investigate the other factors and consequences of organizational performance. 
The combination of both qualitative and quantitative methods can provide holistic view on strategic human capital and its antecedents as well as its relationship with organizational performance

Although the limitation suggest that the rationalization of the results should be interpreted with some caution, the findings of this study provide new insights and better understanding on the makings of strategic human capital in a large manufacturing organization. Organizations, especially large manufacturers, are in intense competitive markets. Optimistically, this study advances knowledge in aligning the significant area of the managers being able to manage their workforce. In this competitive market, this study has not only filled the gaps in the literature, but it also highlights the significance of strategic human capital as a pathway in the relationship between HR configuration and organizational performance.

In conclusion, insights from this study are deemed to expand the knowledge on strategic human capital and to contribute to the existing literature on the subject. It is critical large manufacturing organizations to understand and be aware of the importance of internal factors towards strategic human capital and where it leads to superior organizational performance and also capitalizing on the assets, they possess to enhance organizational performance. In addition, this study tries to educate both the policy makers and the practitioners the importance of strategic human capital and its relationship to organizational performance in the fortification of the nation's economy.

\section{References}

Agarwal, S., Erramilli, M. K., \& Dev, C. S. (2003). Market orientation and performance in service firms: role of innovation. Journal of Services Marketing, 17(1), 68-82.

Amit, R., \& Schoemaker, P. (1993). Strategic Assets and Organizational Rent. Strategic Management Journal, 14(1), 33-46.

Anderson, E. W., \& Fornell, C. (2000). The Customer Satisfaction Index As A Leading Indicator. In Swartz, \& lacobucci, Handbook of Service Marketing and Management (pp. 590-607). Sage.

Arphan, M. A., \& Yap, S. F. (2016). Impact of Malaysia's Capital Market and Determinants on Economic Growth. Journal of Asian Finance, Economics and Business, 3(2), 5-11.

Barney, J. (1991). Firm Resources and Sustained Competitive Advantage. Journal of Management, 17(1), 99-120.

Barney, J., \& Wright, P. M. (1998). On Becoming A Strategic Partner: The Role of Human Resources in Gaining Competitive Advantage. Human Resource Management, 37(1), 3146.

Batistic, S., Cerne, M., Kase, R., \& Zupic, I. (2016 ). The role of organizational context in fostering employee proactive behavior: The interplay between HR system configurations and relational climates. European Management Journal, 1-10.

Becker, G. (2008). 'Human capital'. The Concise Encyclopedia of Economics. Retrieved April 26, 2016, from World Wide Web: http://www.econlib.org/library/Enc/HumanCapital.html

Becker, G. S. (1964). Human Capital : A Theoretical and Empirical Analsis With Special Reference to Education. Chicago: University of Chicago Press.

Bryant-Kutcher, L., Jones, D. A., \& Widener, S. K. (2009). Market valuation of intangible resources: The use of strategic human capital. Advances in Management Accounting, 142.

Brymer, R., Molloy, J., \& Chadwick, C. (2015). Strategic Human Capital. Oxford Bibliographies. 
Cabrales, A. L., Luno, A. P., \& Cabrera, R. V. (2009). Knowledge As A Mediator Between HRM Practices and Innovative Activity. Human Resource Management, 48(4), 485-503.

Calantone, R. J., Cavusgil, S., \& Zhao, Y. (2002). Learning Orientation,Firm Innovation Capability, and Firm Performance. Industrial Marketing Management, 30, 515-524.

Chow, I. H., Huang, J.-C., \& Liu, S. (2008). Strategic HRM in China: Configurations and Competitive Advantage. Human Resource Management, 47(4), 687-706.

Crook, T., Combs, J. G., Todd, S. Y., \& Woehr, D. J. (2011). Does Human Capital Matter? A Meta-Analysis of the Relationship Between Human Capital and Firm Performance. Journal of Applied Psychology, 90(3), 443-456.

Croteau, A.-M., \& Bergeron, F. (2001). An Information TEchnology Trilogy: Business Strategy, Technological Deployment and Organizational Performance. Journal of Strategic Information Systems, 10, 77-99.

Delaney, J. T., \& Huselid, M. A. (1996). The Impact of Human Resource Management Practices on Perceptions of Organizational Performance. Academy of Management Journal, 39(4), 949-969.

Deloitte. (2016). Global Manufacturing Competitiveness Index. London: Deloitte Touche Tohmatsu Limited.

Douglas, M. U. (2016). Finding the niche towards performance excellence. Journal of Facilities Management, 14(4), 330-349.

Economic Planning Unit. (2016). Malaysian Economy in Figures. Malaysia: Economic Planning Unit.

Faul, F., Erdfelder, E., Buchner, A., \& Lang, A. (2009). Statistical power analyses using G* Power 3.1: Tests for correlation and regression analyses. Behavior Research Methods, 41(4), 1149-1160.

Federation of Malaysian Manufacturers. (2015). FMM Directory of Malaysian Industries. Federation of Malaysian Manufacturers.

Felicio, J., Couto, E., \& Caiado, J. (2014). Human capital, social capital and organizational performance. Management Decision, 52(2), 350 - 364.

Franke, G., \& Sarstedt, M. (2019). Heuristics versus statistics in discriminant validity testing: a comparison of four procedures. Internet Research, 29(3), 430-447.

Gao, S.-Y., Ren, L.-J., Zhang, Y.-I., \& Zhang, S.-J. (2012). The Impact Mechanism of Stategic Human Capital on Firm Competitive Advantage. 2012 International Conference on Management Science and Engineering, (pp. 1193-1199). Dallas,USA.

Gao, S.-Y., Xu, L., Zhang, Y.-L., \& Zhang, H.-F. (2013). The Emergence of Strategic Human Capital Unter The Differentiation Strategy : Data from Manufacturing Industry. Proceedings of 20th International Conference on Industrial Engineering and Engineering Management (pp. 921-931). Springer-Verlag Berlin Heidelberg.

Gao, S.-y., Zhang, M., Zhang, Y.-I., Zhang, J., \& Zhang, H.-f. (2013). The VRIO Characteristics of Corporate Strategic Human Capital at Business Level. 2013 International Conference on Management Science \& Engineering, (pp. 827-832). Harbin, P.R.China.

Ghazali, M. S., Kusairee, M. A., Tan, P.-L., Yasin, N. H., \& Yasoa, M. R. (2015). Intention to Migrate : Underlying Factors Affecting Malaysia Brain Drain. The Proceedings of The 4th International Seminar on Entrepreneurship and Business , (pp. 637-647).

Hair, J. F., Hult, G., Ringle, C. M., \& Sarstedt, M. (2016). A Primer on Partial Least Squares Structural Equation Modeling (PLS-SEM) (2 ed.). Sage Publications.

Hair, J. F., Hult, G., Ringle, C. M., \& Sarstedt, M. (2014). A Primer on Partial Least Squares Structural Equation Modeling (PLS-SEM). Sage Publications Inc. 
Hair, J. F., Howard, M. C., \& Nitzl, C. (2020). Assessing measurement model quality in PLS-SEM using confirmatory composite analysis. Journal of Business Research, 109, 101-110.

Hansen, N., Guttel, W., \& Swart, J. (2017). HRM in Dynamic Environments: Exploitative, Exploratory, and Ambidextrous HRM Architectures. The International Journal of Human Resource Management.

Hsu, I.-C. (2008). Knowledge sharing practices as a facilitating factor for improving organizational performance through human capital: A preliminary test. Expert Systems with Applications, 1316-1326.

Ismail, M., Kunasegaran, M., \& Rasdi, R. M. (2014). Evidence of Reverse Brain Drain in Selected Asian Countries : Human Resource Management Lessons for Malaysia. Organizations and Market in Emerging Economies, 5(1).

Ismail, R., Rosa, A., \& Sulaiman, N. (2012). Globalisation and Labour Productivity in the Malaysian Manufacturing Sector. Review of Economics \& Finance, 76-86.

Jin, Y., Hopkins, M. M., \& Wittmer, J. L. (2010). Linking Human Capital To Competitive Advantages : Flexibility In A Manufcaturing Firm's Supply Chain. Human Resource Management, 49(5), 939-963.

Kam, A. J.-Y. (2014). Revisiting the productivity growth and spillovers debate: the case of Malaysian manufacturing sector. Journal of the Asia Pacific Economy, 19(4), 656-681.

Kang, S.-C., Morris, S. S., \& Snell, S. A. (2007). Relational Archetypes, Organizational Learning, and Value Creation: Extending the Human Resource Architecture. The Academy of Management Review, 32(1), 236-256.

Kirby, J. (2005). Toward a theory of high performance. Harvard Business Review, 83, 30-39.

Kock, N. (2015). Common method bias in PLS-SEM: A full collinearity assessment approach. International Journal of e-Collaboration (ijec), 11(4), 1-10.

Lado, A. A., \& Wilson, M. C. (1994). Human Resource Systems and Sustained Competitive Advantage. Academy ol Management Review, 19(4), 699-727.

Lepak, D. P., \& Snell, S. A. (1999). The Human Resource Architecture: Toward a Theory of Human Capital Allocation andDevelopment. The Academy of Management Review, 24(1), 31-48.

Lepak, D. P., \& Snell, S. A. (2002). Examining the Human Resource Arrchitecture: The Relationships Among Human Capital, Employment, and Human Resource Configurations. Journal of Management, 28(4), 517-543.

Liao, S.-H., \& Wu, C.-C. (2009). The Relationship among Knowledge Management, Organizational Learning, and Organizational Performance. International Journal of Business Management, 4(4), 64-76.

Lin, X., \& Tang, H. (2016). A Framework for Human Resource Configurations in Knowledgeintensive Organizations. International Journal of Business Administration, 7(1).

Liu, X., Jaarsveld, D. D., Batt, R., \& Frost, A. (2014). The Influence of Capital Structure on Strategic Human Capital : Evidence from U.S. and Canadian Firms. Journal of Management, 40(2), 422-448.

Mahdi, O., \& Almsafir, M. K. (2014 ). The Role Of Strategic Leadership In Building Sustainable Competitive Advantage In The Academic Environment. Social and Behavioral Sciences, $289-296$.

Malaysia Productivity Corporation. (2016). 23rd Productivity Report 2015/2016. Malaysia Productivity Corporation.

March, J. G., \& Sutton, R. I. (1997). Organizational performance as a dependent variable. Organization Science, 698-706. 
Monks, K., Kelly, G., Conway, E., Flood, P., Truss, K., \& Hannon, E. (2013). Understanding how HR systems work: the role of HR philosophy and HR processes. Human Resource Management Journal, 23(4), 379-395.

Mossholder, K. W., Richardson, H. A., \& Settoon, R. P. (2011). Human Resource Systems and helping in Organizations: A Relational Perspective. Academy of Management Review, 1 , 33-52.

Norriss, S. (2015). The Future of Employee Involvement in Human Resource Management : Indiosyncratic Deals and the HR ARchitecture of the Firm. IBA Thesis Conference. Netherlands: University of Twent, The Faculty of Behavioural, Management and Social Sciences.

Olimpia, N. (2013). Human Capital : Cause and EFfect of the Economic Growth. An Empirical Analysis. The Journal of the Faculty of Economics, 726-735.

Preacher, K. J., \& Hayes, A. F. (2004). SPSS and SAS procedures for estimating indirect effects in simple mediation models. Behavior Research Methods, Instruments, \& Computers, 36(4), 717-731

Preacher, K. J., \& Hayes, A. F. (2008). Asymptotic and resampling strategies for assessing and comparing indirect effects in multiple mediator models. Behavior Research Methods, 40(3), 879-891.

Ramayah, T., Cheah, J., Chuah, F., Ting, H., \& Memon, M. A. (2018). Partial Least Squares Structural Equation Modeling (PLS-SEM) using SmartPLS 3.0: An Updated Guide and Practical Guide to Statistical Analysis (2nd ed.). Kuala Lumpur, Malaysia: Pearson.

Rasiah, R., Crinis, V., \& Lee, H.-A. (2015). Industrialization and Labour in Malaysia. Journal of the Asia Pacific Economy, 20(1), 77-99.

Reijonan, H. (2008). Understanding the small business owner: what they really aim at and how this relates to firm performance : A case study in North Karelia, Eastern Finland. Management Research News, 31(8), 616-629.

Richard, P. J., Devinney, T. M., Yip, G. s., \& Johnson, G. (2009). Measuring Organizational Performance: Towards Methodological Best Practice. Journal of Management, 35(3), 718-804.

Samad, S. (2013). Assessing the Contribution of Human Capital on Business Performance. International Journal of Trade, Economics and Finance, 4(6).

Samagaio, A., \& Rodrigues, R. (2016). Human capital and performance in young audit firms. Journal of Business Research.

Selvaratnam, V. (2016). Malaysia's Higher Education and Quest for Developed Nation Status by 2020. Southeast Asian Affairs, 199-221.

Shakar, S. A., \& Aslam, M. (2015). Foreign Direct Investment, Human Capital and Economic Growth in Malaysia. Journal of Economic Cooperation and Development, 36(1), 103-132.

Sim, S. C., \& Yee, S. V. (2016). Exploring Human Resource Outsourcing Trends in Malaysia. Procedia - Social and Behavioral Sciences, 491-498.

Sim, S. C., Avvari, V. M., \& Kaliannan, M. (2016). HR Outsourcing Trends in Malaysia: The Undetected Tiger. Strategic Outsourcing: An International Journal, 9(2), 189-217.

Su, D., \& Yao, Y. (2016). Manufacturing as the Key Engine of Economic Growth for MiddleIncome Economies. Japan: Asian Development Bank Institute.

Sweetland, S. R. (1996). Human Capital Theory: Foundations of a Field of Inquiry. Review of Educational Research, 66(3), 341-359.

Verburg, R. M., Hartog, D. N., \& Koopman, P. L. (2007). Configurations of human resource management. The International Journal of Human Resource, 18(2), 184-208. 
Walker, E., \& Brown, A. (2004). What Success Factors are Important to Small Business Owners? International Small Business Journal, 22(6), 577-594.

Wang, C., Jaw, B.-S., \& Tsai, C. H.-C. (2012). Building Dynamic Strategic Capabilities: A Human Capital Perspective. The International Journal of Human Resource Management, 23(6), 1129-1157.

Wang, I.-M., Shieh, C.-J., \& Wang, F.-J. (2008). Effect of Human Capital Investment on Organizational Performance. Social Behaviour and Personality, 36(8), 1011-1022.

Widener, S. K. (2004). An Empirical Investigation of The Relation Between The Use of Strategic Human Capital and The Design of The Management Control System. Accounting, Organizations and Society, 377-399.

Wright, P. M., Coff, R., \& Moliterno, T. P. (2014). Strategic Human Capital: Crossing the Great Devide. Journal of Management, 40(2), 353-370.

Wright, P. M., McMahan, G. C., \& McWilliams, A. (1994). Human resources and sustained competitive advantage: a resource-based perspective. International Journal of Human Resource Management, 5(2), 301-326.

Xu, L., Gao, S.-Y., Zhang, H.-F., Yu, H., \& Song, C.-Y. (2016). Strategic Human Capital in Organization: Frontier Review, Prospective Commentary, and Guiding Framework. Proceedings of the 22nd International Conference on Industrial Engineering and Engineering Management (pp. 85-98). Atlantis Press.

Yusoff, R. B., Imran, A., Qureshi, M. I., \& Kazi, A. G. (2016). Investigating the Relationship of Employee Empowerment and Sustainable Manufacturing Performance. International Review of Management and Marketing, 6, 284-290.

Zhang, Y.-I., Gao, S.-Y., \& Zhang, J. (2011). Competitive Strategy, Strategic Human Capital and Sustained Competitive Advantage. International Conference on Management Science \& Engineering (pp. 524-531). Rome, Italy: IEEE.

Zikmund, W. G., Babin, B. J., Carr, J. C., \& Griffin, M. (2013). Business Research Methods. Cengage Learning. 